\title{
The seed coat as a modulator of seed-environment relationships in Fabaceae
}

\author{
FRANCISCO H. DÜBBERN DE SOUZA ${ }^{1,3}$ and JÚLIO MARCOS-FILHO ${ }^{2}$
}

\section{Review article}

\begin{abstract}
The seed coat as a modulator of seed-environment relationships in Fabaceae). The seed coat is one of the main determinants of seed germination, vigor and longevity potentials. It is also intimately associated with temporal and spatial dispersion of seed germination in a large number of plant species. The understanding of its properties and characteristics may explain, anticipate or even allow the modification of seed performance under certain environmental conditions. There is a growing volume of evidence associating seed coat characteristics to specific seed problems. For example, susceptibility to mechanical damage is related to lignin content of the seed coat, while seed longevity and tolerance to field weathering depends on seed coat integrity. Seed performance in many legumes has been associated with certain seed coat structures, such as the hilum, strophiole and micropyle. In soybean, permeability is also related with porosity, color, and cerosity, that affect seed vigor, storage potential, resistance to shrinking and fungi infection, and to susceptibility to imbibition damage. The understanding of these associations is necessary before genetic alterations through breeding for desirable characteristics and is fundamental for the development and improvement of seed pre-sowing treatments, production, handling and quality evaluation procedures, which may ultimately result in reduction of seed quality losses and increase the efficiency of agricultural production systems.
\end{abstract}

RESUMO - (O tegumento como modulador das relações da semente com o ambiente em Fabaceae). O tegumento é um dos principais condicionantes da germinação, do vigor e da longevidade de sementes. A compreensão da sua estrutura e propriedades pode contribuir para explicar, antecipar ou alterar o comportamento de sementes sob determinadas condições ambientais. Grande parte das características do tegumento está associada a problemas específicos apresentados pelas sementes. Assim, por exemplo, susceptibilidade a danos mecânicos está associada ao seu teor de lignina, enquanto que longevidade e potencial de deterioração no campo têm sido relacionados ao grau de permeabilidade do tegumento. Em leguminosas, o grau de permeabilidade da semente está associado ao comportamento de determinadas estruturas presentes no tegumento (hilo, estrofíolo, micrópila). Especificamente no caso da soja, a permeabilidade está também associada à porosidade, cor e cerosidade, que influenciam o vigor, o potencial de armazenamento, o grau de resistência ao enrugamento, à infecção por microorganismos, à danos por embebição, etc. A compreensão destas associações é necessária antes de qualquer tentativa de alteração via melhoramento genético de características indesejáveis, é fundamental ao desenvolvimento e aperfeiçoamento de práticas adequadas de manuseio, produção e de testes de avaliação de qualidade de sementes que poderão resultar na redução de perdas de qualidade de sementes e no aumento da eficiência dos sistemas de produção agrícolas.

Key words - Germination, vigor, imbibition, dormancy

\section{Introduction}

The seed coat is the outer covering of every mature seed. Among its many functions are: preservation of the integrity of the seed parts, protection of the embryo against mechanical injuries and attacks of pests and diseases, regulation of gaseous exchanges between the embryo and the external environment and, in many species, participation in the process of seed dispersal.

1. Embrapa Pecuária Sudeste, Caixa Postal 339, 13560970 São Carlos, SP, Brazil.

2. USP/ESALQ, Departamento de Produção Vegetal, Caixa Postal 9, 13418-900 Piracicaba, SP, Brazil. Bolsista do CNPq.

3. Autor para correspondência: fsouza@cppse.embrapa.br
Another important function is regulating imbibition. In several plant families, the seed coat plays a role in the control of water absorption, and hence on germination, often representing a temporarily impermeable barrier. In this review emphasis will be given to seed coat effects in the Fabaceae.

The seed coat (often referred to as testa) is, therefore, the main modulator of interactions between the internal structures of the seed and the external environment. A better understanding of its anatomical and morphological characteristics might contribute to explain, predict or, even, allow manipulation (through scarification, e.g.) or permanent alteration (through breeding) of seed performance under certain environmental conditions.

Seed coat function and properties have been the subject of reviews, each reflecting specific interest (e.g. Ballard 1973, Rolston 1978, Peske \& Pereira 1983, 
Swanson et al. 1985, Woodstock 1988, Argel \& Paton 1999). A renewed interest in this topic has arisen, especially for seed coat deterioration under field conditions for important agronomic crops such as cotton (Gossypium hirsutum) and, specially, soybean (Glycine max).

A comprehensive view on the modulatory role played by the mature seed coat in Fabaceae, upon embryo's interactions with the external environment may be specially important for seed technologists and biologists and plant breeders; it may also contribute to the identification of topics of controversy, gaps in the knowledge on the subject and, eventually, of topics in need of research. We made these the objectives of this review.

\section{Seed coat: origin, structures and characteristics}

Seed coat structure differs among species and varieties. It is, sometimes, represented by a rudimentary testa, in which case, the first external covering is the pericarp, derived of the ovary wall. In the Fabaceae the seed coat originates from the two- ovule integuments. During seed ontogeny, the outer integument gives rise to several distinct layers transforming itself into the testa, while in many species, the inner integument disappears (Esau 1977, Miller et al. 1999). Especially among Glycine and Phaseolus species, the seed coat is a true testa. Its basic structure (figure 1) is remarkably similar among different species, consisting of four layers. Inwards from the surface they are: the waxy cuticle layer, the epidermis, the hypodermis, and the interior parenchyma (Swanson et al. 1985). It is the microstructure and chemical composition of these layers that give rise to species and varieties differences in seed coat structure and function.

The outermost layer is the waxy cuticle, of variable thickness, which represents the first barrier to imbibition. Actually, for soybean seeds, two layers of waxy deposits, one very stable and the other environmentally labile are suggested (Ragus 1987). The epidermis, a layer of thick-walled, elongated palisade cells, called macrosclereids, with the long axis oriented perpendicularly to the surface, composes the next layer. In some species, a light refractive, apparently denser region can be

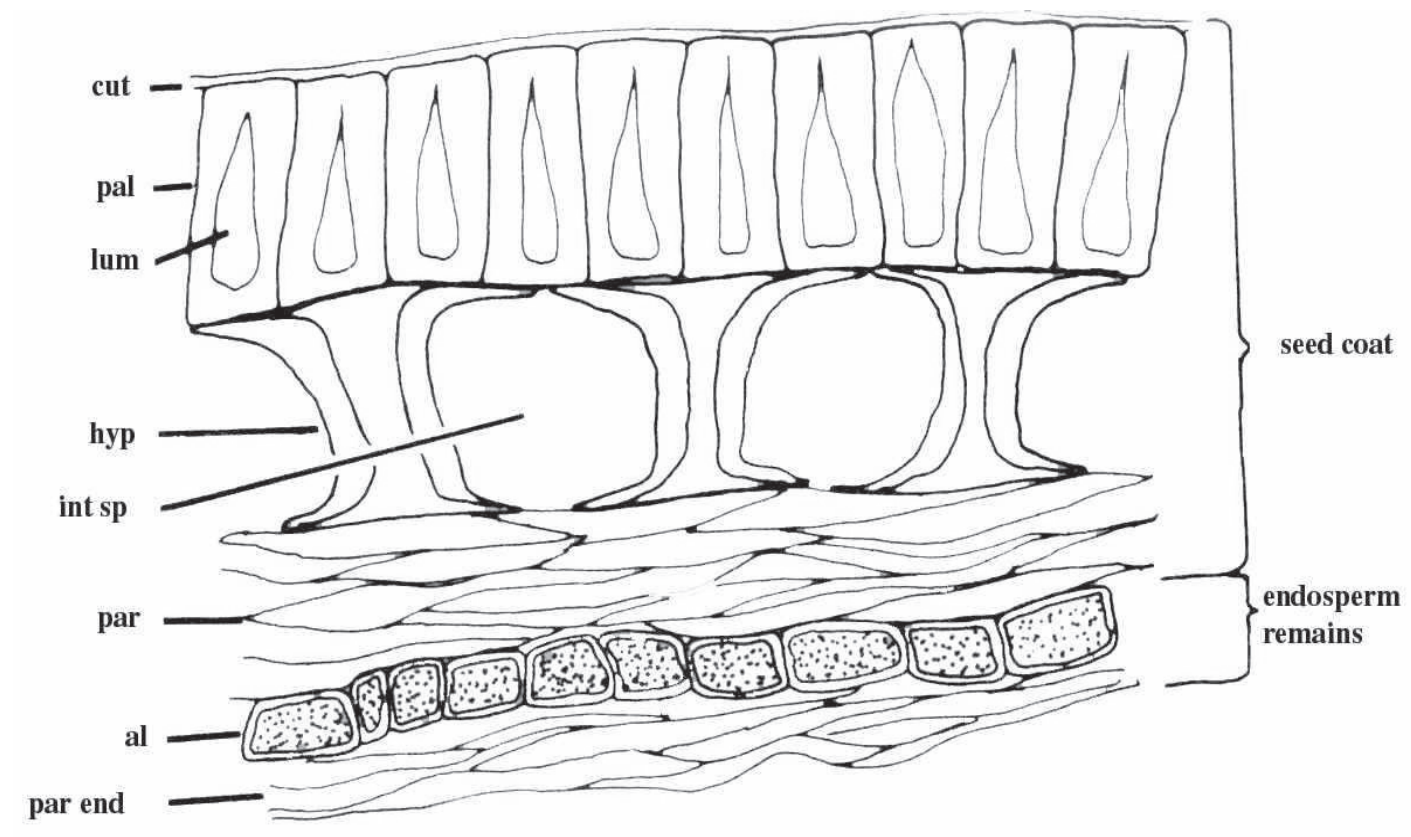

Figure 1: Seed coat anatomy of soybean [Glycine $\max ($ L.) Merr.] cultivar "Hawkeye".

Abbreviations: al - aleurone cells, cut - cuticle, hyp - hourglass cells of hypodermis, int sp. - intercellular space, lu - lumen, pal - palisade, par - compressed parenchyma cells, and par end - remains of parenchyma cells of endosperm. X 535.

From: Carlson \& Lersten 1987 (Reproduced with permission). 
distinguished using optical microscopes, called "linea lucida" or "light line". Only one palisade layer is found throughout the testa, except under the hilum where two can occur, of which the external layer is called the counter-palisade and originates from the funiculus (Peske \& Pereira 1983).

A single layer of cells forms the hypodermis, which is also, called hourglass cells, pillar cells, osteosclereids or lagenosclereids, depending on their pattern of cell wall thickness and shape. They are usually larger than adjacent cell layers and are separated by wide intercellular spaces, except under the hilum cleft where they are absent. The fourth layer of the seed coat is the interior parenchyma, formed by six to eight layers of thin-walled, protoplast-free, tangentially elongated parenchyma cells, uniformly distributed throughout the whole testa, except in the area of the hilum, where a smaller number of layers can be distinguished. In mature seed coats, the interior parenchyma is often crushed or partially so (Miller et al 1999).

Rapid cotyledon growth sometimes is not adequately matched by the expansion of the testa and cracks are formed as a result, affecting seed quality (Agrawal \& Menon 1974). In soybean, the relative weight proportion represented by the seed coat decreases as seed weight increases (Calero et al. 1981). The testa influences cotyledon growth rates and, ultimately, seed size in legume species (Egli 1990). However, Lush \& Evans (1980) found no evidences that a thick testa restricts seed by mechanically restricting growth in Vigna unguiculata and thus small seeds were not always associated with thick seed coat or large seeds with thin ones. There seems to exist, however, an association between seed coat thickness and the degree of domestication of genotypes; wild or more primitive cultivated types tend to present thicker seed coats (Lush \& Evans 1980).

The extrahilar region of the seed coat varies according to genotype in terms of texture, color, hardness, porosity, pilosity, and presence of scars and appendages. Different regions of the seed coat present different thickness (Pereira \& Andrews 1985, Noodén et al. 1985) and water uptake varies accordingly (Ballard 1973). Other substances, such as tannins, phenols, waxes, pigments and germination inhibitors, capable of influencing subsequent development, may also be found in seed coats of different species (Woodstock 1988).
Other structural features can be found in the seed coat; their relevance to the process of water absorption as well as other properties of the seed varies according to species and variety. The hilum is a particularly important structure controlling embryo external environment relationships. Situated close to one of the hilum extremities the micropyle (a small opening remnant from the embryo sac) is sometimes naturally closed by a waxy "lid" which may function to regulate pathogen susceptibility (Saio 1976), besides water absorption, in seeds of different soybean cultivars (Vaughan et al. 1987). In some species, in one of the extremities of the hilum, the strophiole (also called the raphe or lens), a predetermined, inherently weak area of the seed coat, can be distinguished. Under certain environmental conditions, it ruptures, forming a reversible cleft; in other species, a strophiolar plug erupts irreversibly, leaving a cavity on the seed coat (Hopkinson 1993).

In soybean seeds, small openings, denominated pores or, sometimes, pits, appear unevenly distributed throughout the testa surface (La Scala Jr. et al. 1999 , among others). Their formation occurs at a relatively advanced stage of seed development, and coincides with the beginning of the desiccation phase (Yaklich et al. 1986, Vaughan et al. 1987). Pores vary in number, form and size, according to genotype; in some cultivars they cross the palisade layer of the testa (Calero et al. 1981, Wolf et al. 1981).

Most morphological features of the seed coat are relatively insensitive to environment conditions and thus useful for taxonomic identification (Gunn 1981, Jha \& Pandey 1989). In Brassica and allied genera, high magnification studies revealed that seed coat microsculpturing patterns are species- but not genus-specific (Koul et al. 2000). Seed coat color is influenced by environmental conditions and therefore not appropriate for taxonomic purposes.

Seed coat is formed by maternal genotype. Environment can promote nongenetic maternal changes in the seed coat, such as thickness and composition, which do not persist beyond one generation. This fact was particularly evident in several studies carried out with Plantago lanceolata [Plantaginaceae] (Lacey et al. 1997). While temperature effects on germination are mediated by the seed coat, the embryo mediates other, more persistent, effects of temperature on parental effects (Case et al. 1996). 
Tissues of developing seed coat can be targeted for modification of gene expression aiming to influence properties of mature seeds (Miller et al. 1999). Important steps in this direction have been taken, with the identification of genes specifically associated with seed coat characteristics in soybean (Batchelor et al. 2000) and P. vulgaris (Beninger et al. 2000); however, further achievements in this area might be delayed by pleiotropic effects demonstrated by these genes (Beninger et al. 2000). Colordetermining genes, for example, influence other seed characteristics such as rate of imbibition (Swanson et al. 1985, Powell 1989), seed coat anatomy (Beninger et al. 2000) and ratio between seed coat mass and whole bean dry mass (Beninger et al. 1998).

Interestingly, in several Glycine spp the membranous inner endocarp epidermis detaches from other tissues of the pod wall and adheres to the seed surface becoming part of the mature seed coat. The large amounts of hydrophobic protein found in these adherences may prevent pathogen attachment and penetration on the seed coat, influence water absorption properties of the seed or act as a feeding deterrent or toxin against other organisms; thus, it may also be possible to alter seed coat characteristics through manipulation of gene expression in the ovary wall (Gijzen et al. 1999).

\section{Seed coat and water absorption}

Water may reach the embryo in a variety of ways. In soybean, while some authors concluded that water reaches the embryo mainly through the testa (Noodén et al. 1985, Chachalis \& Smith 2000), others suggested that water entrance occur mainly through the hilar area (McDonald et al. 1988a). The hilum, the micropyle and the raphe have been suggested as path of water imbibition Phaseoulus lunatus (Korban et al. 1981) and P. vulgaris (Agbo et al. 1987); Korban et al. (1981) associated these differences with different cultivars.

Sefa-Dedeh \& Stanley (1979) concluded that during the first $3 \mathrm{~h}$ to $12 \mathrm{~h}$ the hilum size was the most important controller of imbibition in cowpea $(V$. unguiculata) seeds while the percentage of protein in the cotyledon was important between $12 \mathrm{~h}$ and $24 \mathrm{~h}$ of imbibition. However, since the seeds absorbed nearly $80 \%$ in the first three hours, it was concluded that thickness of the seed coat was the most important factor. In soybean, the seed coat initially retards water absorption but gradually facilitates the movement of water to the embryo, allowing both cotyledons to imbibe uniformly; it may also acts as a water reservoir for the initial steps of the germination (McDonald Jr. et al. 1988b).

Water absorption rates are high in soybean seeds whose embryo/endosperm volumetric relationship is large; a seed coat/embryo weight ratio smaller than 0.1 might indicate a permeable seed coat (Yaklich et al. 1986). This ratio-permeability relationship, however, does not hold for all genotypes (Chachalis $\&$ Smith 2000). Temperature, solute concentration and initial moisture content were found to be highly correlated with maximal rate of water absorption by soybean seeds, while protein content, seed density and seed size were less correlated (Hsu et al. 1983).

Porous seed coats are usually permeable and non-porous ones impermeable (Yaklich et al. 1984) but the number of pores per unit of testa area is not the sole regulator of water absorption rates by soybean seeds (Calero et al. 1981, Yaklich et al. 1984). Moreover, genotypes with impermeable, albeit porous, seed coat were identified (Yaklich et al.1986). Absorption rates are lower where the pores are narrow, elongated and where the epidermis is covered by a dense, embedded, waxy layer (Calero et al. 1981, Ragus 1987) probably originated from the pod endocarp (Yaklich et al. 1984).

In many cases, the control of water absorption is conferred by the hydrophobic nature of the testa which, depending on the species, can present different degrees of cutinization of the palisade cells (Calero et al. 1981, Yaklich et al. 1986, Ragus 1987) or concentration of waxy or phenolics substances in the epidermis (Marbach \& Mayer 1974, Ragus 1987).

Color is another seed coat characteristic associated with water absorption. Seed coat pigmentation is correlated with slow rates of imbibition in several legume species. Compared with unpigmented seed coats, a higher degree of shrinkage of the pigmented ones and, hence, a greater adherence to the cotyledons during maturation results in low rates of imbibition (Asiedu \& Powell 1998, and references cited therein).

Browning of seed coat during seed maturation, however, was found to be associated with its impermeabilization in P. vulgaris, Cicer arietinum, $V$. unguiculata (Legesse \& Powell 1996) an in wild species of Pisum (Werker et al. 1979) but not in Trifolium subterraneum (Slattery et al. 1982) or 
Stylosanthes hamata (Argel \& Humphreys 1983) where these two process seems to occur independently. Browning results from the oxidation of phenolics, which are present in high levels in pigmented seed coats (Legesse \& Powell 1996).

\section{Seed coat-imposed dormancy}

Plant species of fifteen different families are capable of producing seeds whose coats are temporarily impermeable to water and, perhaps, gases. Such seeds will not germinate even if submitted to conditions ideal for germination; they are called "hard seeds". Among these families is the Fabaceae, of which most species produce hard seeds (Baskin \& Baskin 1998). This mechanism of physical dormancy sometimes appears in association with other types of dormancy in a few legume species (Owen 1956, Evans \& Smith 1999).

Hard seed production contributes to the temporal dispersion of germination, avoiding the risks of synchronous germination of the entire seed bank. Hardseededness increases the survival rate of seeds in its passage through the digestive tract of many animal species (Simão Neto et al. 1987) which, in consequence, act as agents of spatial seed dispersal. Rapid recolonization of burned areas by certain species is made possible by soil-accumulated hard seeds, rendered permeable by fire (Dell 1980). Among forage legumes, the accumulation of hard seeds in the soil seed bank allows the perennization of plant populations in pastures (Argel \& Paton 1999).

However, hard seeds also contribute to the accumulation of weed seed banks in agricultural areas, allowing the recurrence of problem species long after the mother plants have been eliminated. Moreover, the presence of hard seeds in seed lots of agricultural crops is undesirable because they contribute to heterogeneous seedling emergence (Woodstock 1988, Argel \& Patton 1999), potentially reducing yields, delaying harvest (Baciu-Miclaus 1970) and diminishing the stand ability to compete with weeds. Impermeable seeds are also a problem in food processing due to its undesirable effects upon product quality (Hsu et al. 1983).

Seed coat hardening is an inheritable character controlled by one or few genes highly influenced by the environment (Ramsay 1997, among others). The basic histological structure of permeable and impermeable testa is identical, (Harris 1987, Valenti et al. 1989) and, therefore, impermeability is not a consequence of a special layer of cells; rather, it results from a particular chemical composition of cells that are part of the seed coat anatomy of these species (Argel \& Paton 1999). Although thick seed coats seems to be required for seed hardness, thickness alone does not account for impermeability since even in a thick seed coat, water may access the embryo via specialized regions such as the hilum, lens or raphe.

Seeds become impermeable during the later stages of maturation (Gillikin \& Graham 1991). The biochemical mechanism of the hardening process may vary among plant families (Egley et al. 1983) and the specific site of impermeability within species varies according to genotype. In soybean, seed coat impermeability has also been associated with the waxy cuticle (Arechavaleta-Medina \& Snider 1981), high calcium and low phosphorus seed coat concentrations (Saio 1976), high xylose concentration (Mullin \& Xu 2000), to a phenolic layer, lack of pores, a prominent light line and cutin in the hilum region (Harris 1987), to embedded waxy substances between the palisade cells and to high lignification of the palisade cell base and the hypodermal cell tops (BaciuMiclaus 1970) and to the presence, number and shape of pores (Yaklich et al. 1986).

Peroxidase is a major component of the protein fraction in mature soybean seed coats (Gillikin \& Graham 1991). It is involved with lignification in different plant organs of several species as well as with the polymerization of soluble phenolics to insoluble polymers, such as lignin. It is particularly active during seed coat development in Sida spinosa (Malvaceae) and, possibly, wild pea (Egley et al. 1983) and soybean (Mullin \& Xu 2000), promoting impermeabilization. Studies carried out by Werker et al. (1979) with several Pisum species indicated that testa impermeability depends on the presence of quinones in the palisade or osteosclereids layer as a continuous layer. Catechol oxidase, which is responsible for quinone oxidation, is not produced in every layer of the testa and each species has its own site of production.

The production of seeds with thick, impermeable coat may be a consequence of a reduction in the flux of mineral nutrients and, specially, cytokinin, from the roots, resulting from adverse environmental conditions experienced by the mother plant (Noodén et al. 1985). In fact, high temperatures, low air relative humidity (Argel \& Paton 1999) and water stress (Hill 
et al. 1986) favor hard seed production. Thus, the proportion of hard seeds produced by legume species varies according to year and geographic location (Calero et al. 1981, among others). In several species, the proportion of hard seeds increases as seed size decreases (Yaklich et al. 1986, Ragus 1987, Souza et al. 1996).

In the final stages of this process, seed water content is controlled by the hilum, which opens when humidity is low and closes to prevent water absorption by the seed when the humidity is high. As the embryo water content decreases to about $10 \%$ of the seed dry weight, the hilum closes and a condition of absolute impermeability is established (Hyde 1954, Lush \& Evans 1980). Thus, seed water content at this point reflects the hygroscopic equilibrium established with the smallest relative humidity of the atmosphere to which the developing seeds were exposed, and the chemical composition of the seed (Hyde 1954). This might explain the greater longevity of hard seeds compared to that of permeable ones (Maxey \& Delouche 1980, Wien \& Kueneman 1981).

Seed coat impermeability can also occur after harvest, during storage. In legume species from temperate climates, storage under low relative humidity favors the transformation from permeable to hard seed, while storage under high relative humidity has a reverse effect. While storage under low temperatures result in the formation of a smaller number of hard seeds, the seeds remain dormant for longer periods, possibly due to factors other than hardseededness; storage under high temperature has the reverse effect (Owen 1956). At least in some cases, the reversibility phenomenon seems to be related with the structure of the strophiole. In seeds of Mimosoideae and Caesalpinioideae subfamilies this structure is irreversibly eruptive, while among Papilionaceae species, it has a cleaving, reversible nature (Hopkinson 1993).

This type of dormancy is naturally overcome, as water and gases are gradually allowed to penetrate the seed via one or several pathways. Depending on the species and variety, these pathways are: epidermal cracks or pores (Peske \& Pereira 1983); strophiole (Hamly 1932); hilum (Hyde 1954); micropyle (Ragus 1987); chalasa (Spurný 1973); raphe (Lush \& Evans 1980); or the epidermis, which becomes more permeable as the seed ages (Maxey \& Delouche 1980).
Genetic factors and environmental conditions during plant growth determine the maximum proportion of hard seeds produced by the plant while genotype controls the rate of natural permeability increase of these seeds (Tinius 1991). Under natural conditions this happens as a consequence of effects exerted upon these structures by temperature and humidity fluctuations (Argel \& Paton 1999), constant high temperatures (Nakamura 1962), fire (Dell 1980), attacks of microorganisms and organic acids and ingestion by animals (Mayer \& Poljakoff-Mayber 1975). Large variation in threshold temperature and dormancy breakdown rates among seed lots of same legume cultivars or accessions, and among tropical legume species has been reported (McDonald 2000).

Hardseedeness may also be artificially overcome by a variety of thermal, chemical and physical treatments; Argel \& Paton (1999) amply discussed the many alternatives used with forage legume seeds, many of which are used commercially.

\section{Seed coat and seed physiological quality}

Being a physical process, driven primarily by an osmotic gradient established between the seed and a moist substratum, water imbibition does not depend on the physiological status of the seed. This is evident in studies in which the seed coat was excised; however, when intact seeds were used, vigor and viability correlated negatively with the amount of water absorbed (Souza \& Marcos-Filho 1993, and references cited therein).

Immature and seed coat-damaged seeds, often present lower vigor and viability potentials as well as more permeable seed coats (Oliveira et al. 1984, among others). Permeability may be altered by cracks, cleavages, fissures, and scratches resulting from handling procedures (e.g., harvesting, drying, processing and sowing operations), insect attack or certain environmental conditions during seed maturation. An intact seed coat is capable of regulating the speed of water absorption protecting the embryo from injuries which might otherwise result from rapid imbibition, but this condition does not always suffice (Chachalis \& Smith 2000).

In recent years, a growing interest in the genetic incorporation of specific seed coat traits associated with imbibition control in soybean genotypes breeding has occurred, with the aim of increasing seed storage potential and reducing field deterioration 
(Potts et al. 1978, and several others). This would be especially important in tropical regions, where field deterioration often occurs due to water absorption from the atmosphere by mature, permeable seeds before harvest. Another important possibility is the reduction of susceptibility to mechanical damage.

The positive correlation often found between seed size and testa permeability has led several authors to conclude that the soybean lineages best adapted to tropical conditions are the small-seeded ones (Mugnisjah et al. 1987, and others). However, soybean seed longevity, resistance to deterioration under field conditions and seed size are not always associated (Kuo 1989, Horlings et al.1991). Moreover, the presence of as little as $1 \%-2 \%$ of hard seeds in a seed lot could be enough to negate any eventual reduction in field deterioration resulting from slow water uptake imposed by the testa (Potts et al. 1978). Thus, legume cultivars with seed coat capable of delaying imbibition, instead of impeding it, were suggested as better alternatives (Kuo 1989, Chachalis \& Smith 2000).

Soybean cultivars differ both in terms of susceptibility to mechanical damage (Carbonell et al. 1992, Carbonell \& Krzyzanowski 1995) and lignin content of the seed coat, a trait which is negatively correlated with seed coat permeability (Tavares et al. 1987, Panobianco et al. 1999) and positively correlated with resistance to mechanical damage (Alvarez et al. 1997). Whether or not lignin content in the seed coat is correlated with seed coat thickness is a matter of controversy (Agrawal \& Menon 1974, Tavares et al. 1987). Cultivars of $P$. vulgaris resistant to seed coat cracking have uniform seed coat thickness and a thick seed coat (Korban et al. 1981). Tannin testa concentration was found to be associated with rate of water absorption, percentage of hard seed and incidence of testa cracking in Vicia faba (Kantar et al. 1996).

In a large number of legume species, seed coat color changes during storage, according to prevailing environmental conditions; in these cases, changes occur concomitantly with seed physiological deterioration and increase in seed coat permeability (Silva et al. 1988, among others). Seeds with unpigmented seed coat deteriorate more rapidly and are more susceptible to imbibition damage (Abdullah et al. 1991, Asiedu \& Powell 1998). In fact, an association between rapid imbibition and white or partially white-coated seeds has been observed in cultivars of a large number of legume species; seeds of other colors tend to absorb slowly. This property has been attributed to seed coat permeability, adherence of the seed coat to cotyledons and thickness of the testa (Legesse \& Powell 1996, and references cited therein).

On the other hand, black coated soybean seeds have slower initial imbibition rates (Kuo 1989, Chachalis \& Smith 2000), higher resistance to field deterioration, thicker (Tully et al. 1981, Mugnisjah et al. 1987) and tougher (Tully et al. 1981) testas, higher lignin contents and fungicidal properties (Krzyzanowski et al. 1999) in comparison with nonblack seed coated cultivars. These are examples of pleiotropic effects of seed coat-related genes yet to be studied in greater detail.

Verma \& Ram (1986) concluded that it would be easier to genetically improve soybean storability than seed coat permeability, as measure by its leachate characteristics. However, the ratio between seed coat weight and total seed weight was proposed as useful selection criteria for prediction of seed longevity in soybean cultivars since high ratios were found to be associated with higher seed longevity potential (Tiwari \& Hariprasad 1997).

Several seed coat features represent routes of pathogenic fungi penetration into the seed. As shown in soybean cultivars, the routes invasion vary with pathogen (Vaughan et al. 1988) and some of them have marked preference for natural openings in the seed coat such as pits, micropyle and hilum. Kulik \& Yaklich (1991) observed that soybean cultivars with high percentages of hard seeds and whose seed coat had no pores and a closed micropyle had low Phomopsis phaseoli infection while those with low percentages of hard seed and seed coat with multiple pores and open micropyles had high infection.

Permeability, a property associated to heritable seed coat characteristics, restricts the applicability of certain seed quality evaluation procedures. This is the case of the electrical conductivity test, which consists in measuring electrical conductivity of electrolytes leached from imbibed seeds; conductivity readings and degree of seed deterioration are positively correlated (Vieira 1994, among others). Since water imbibition and electrolyte leaching are reverses of a same coin, the conductivity test estimates seed coat permeability as well (Kuo 1989).

This test is more precise for comparing physiological quality among seed lots from a same 
cultivar than among lots of different cultivars (Prete et al. 1994, Dias \& Marcos-Filho 1996, Panobianco \& Vieira 1996, Vieira et al. 1996). Thus, critical, threshold, electrical conductivity values, such as those proposed for soybeans by Vieira et al. (1999) should perhaps be characterized for each individual cultivar or groups of cultivars sharing identical seed coat characteristics. Possible influences of genotype on the performance of seeds submitted to other vigor tests such as the accelerated aging test were indicated by Marcos-Filho (1994) but the role of the seed coat on this performance remains unclear.

\section{Conclusions}

The association between specific seed coat physical, chemical, morphological and anatomic characteristics with patterns of seed performance under different environmental circumstances is a well documented fact. Despite sharing identical basic anatomical testa structure, legume species vary widely in seed coat microstructure and the path and pattern of water absorption by their seeds vary in consequence. Recognition of this variability is a primary requisite for the development of accurate seed testing evaluation procedures as well as of efficient production, handling and processing practices.

Since these characteristics vary not only among species but also among varieties and cultivars, the range of possibilities seems ample for plant breeders aiming the attenuation of specific seed problems through breeding. Pleiotropic gene effects, as reported for several genotypes, however, might hamper the achievement of this goal. The reckoning of the pod as a determinant of seed coat characteristics, as found in soybean, may also represent important implications to breeding for seed coat properties as well.

The utilization of molecular strategies for altering and understanding the genetic control of seed coat development, properties and characteristics depends on cloning seed-coat specific genes; a few, significant steps have recently been taken in this direction.

Understanding the many roles of the seed coat as a modulator of the relationships between seed and environment is fundamental for scientists from diverse backgrounds in their quest to feed the world's population through ecological-friendly, sustainable agricultural systems.
Acknowledgements - The authors are grateful to Dr. Francisco C. Krzyzanowski (Embrapa Soja, Londrina - PR) for valuable suggestions and to Dr. Amadeu Regitano Neto, Post-Doctor supported by FAPESP at Embrapa Pecuária Sudeste (São Carlos - SP), foring review the text.

\section{References}

ABDullah, W.D., POWEll, A.A. \& MATtheWs, S. 1991. Association of differences in seed vigour in long bean (Vigna sesquipedalis) with testa colour and imbibition damage. Journal of Agricultural Science 116:259-264.

AGBO, G.N., HOSFIELD, M.A., UEBERSAX, M.A. \& KLOMPARENS, K. 1987. Seed microstructure and its relationship to water uptake in isogenic lines and a cultivar of dry beans (Phaseolus vulgaris L.). Food Microstructure 6:91-102.

AGRAWAL, K. \& MENON, K. 1974. Lignin content and seed coat thickness in relation to seedcoat cracking in soybean. Seed Research 2:64-66.

ALVAREZ, J.C., KRZYZANOWSKI, F.C., MANDARINO, J.M.G. \& FRANÇA-NETO, J.B. 1997. Relationship between soybean seed coat lignin content and resistance to mechanical damage. Seed Science and Technology 25:209-214.

ARECHAVALETA-MEDINA, F. \& SNYDER, H.E. 1981. Water imbibition by normal and hard soybeans. Journal of the American Oil Chemists Society 58:976-979.

ARGEL, P.J. \& HUMPHREYS, L.R. 1983. Environmental effects on seed development and hardseededness in Stylosanthes hamata cv. Verano. I. Temperature. Australian Journal of Agricultural Research 34:261-270.

ARGEL, P.J. \& PATON, C.J. 1999. Overcoming legume hardseededness. In Forage seed production: Tropical and sub-tropical species (D.S. Loch \& J.E. Ferguson, eds.). v.2, chapter 14, CAB International, Wallingford, p.247-265.

ASIEDU, E.A. \& POWELL, A.A. 1998. Comparisons of the storage potential of cultivars of cowpea (Vigna unguiculata) differing in seed coat pigmentation. Seed Science and Technology 26:211-221.

BACIU-MICLAUS, D. 1970. Contributions to the study of hard seed and coat structure properties of soybeans. Proceedings of the International Seed Testing Association 35:599-617.

BALLARD, L.A.T. 1973. Physical barriers to germination. Seed Science and Technology 1:285-303.

BASKIN, C.C. \& BASKIN, J.M. 1998. Seeds: ecology, biogeography, and evolution of dormancy and germination. Academic Press, San Diego, 666 p.

BATCHELOR, A.K., BOUTILIER, K., MILlER, S.S., LABBÉ, H., BOWMAN, L., HU, M., JOHNSON, D.A., GIJZEN, M. \& MIKI, B.L.A. 2000. The seed coat-specific expression of a subtilisin-like gene, SCS1, from soybean. Planta 211:484-492.

BENINGER, C.W., HOSFIELD, G.L. \& NAIR, M.G. 1998. Physical characteristics of dry beans in relation to seed coat color genotype. HortScience 33:328-329.

BENINGER, C.W., HOSFIELD, G.L., BASSET, M.J. \& OWENS, S. 2000. Chemical and morphological expression of the $B$ and Asp seedcoat genes in Phaseolus vulgaris. Journal of the American Society of Horticultural Science 125:52-58. 
CALERO, E., WEST, S.H. \& HINSON, K. 1981. Water absorption of soybean seed and associated causal factors. Crop Science 21:926-933.

CARBONELL, S.A.M. \& KRZYZANOWSKI, F.C. 1995. The pendulum test for screening soybean genotypes for seed resistant to mechanical damage. Seed Science and Technology 23:331-339.

CARBONELL, S.A.M., KRZYZANOWSKI, F.C. \& KASTER, M. 1992. Avaliação do "teste de queda" para seleção de genótipos de soja com semente resistente ao dano mecânico. Revista Brasileira de Sementes 14:215-219.

CARLSON, J.B. \& LERSTEN, N.R. 1987. Reproductive morphology. In Soybeans: Improvement, production, and uses. (J.R. Wilcox, ed.). $2^{\text {nd }}$ ed. Chapter 4. Monograph 16. American Society of Agronomy, Winsconsin, p.95134.

CASE, A.L., LACEY, E.P. \& HOPKINS, R.G. 1996. Parental effects in Plantago lanceolata L. II. Manipulation of grandparental temperature and parental flowering time. Heredity 76:287-295.

CHACHALIS, D. \& SMITH, M.L. 2000. Imbibition behavior of soybean (Glycine max (L.) Merril) accessions with different testa characteristics. Seed Science and Technology 28:321-331.

DELL, B. 1980. Structure and function of the strophiolar plug in seeds of Albizia lophantha. American Journal of Botany 67:556-563.

DIAS, D.C.F.S. \& MARCOS-FILHO, J. 1996. Testes de condutividade elétrica para avaliação do vigor de sementes de soja [Glycine max (L.) Merril]. Scientia Agricola 53:31-42.

EGLEY, G.H., PAUL Jr., R.N., VAUGHN K.C. \& DUKE, S.O. 1983. Role of peroxidase in the development of waterimpermeable seed coats in Sida spinosa L. Planta 157:224-232.

EGLI, D.B. 1990. Seed water relations and the regulation of the duration of seed growth in soybean. Journal of Experimental Botany 41:243-248.

ESAU, K. 1977. Anatomy of seed plants. $2^{\text {nd }}$ ed. John Wiley, New York. 550p.

EVANS, P.M. \& SMITH, F.A. 1999. Patterns of seed softening in subterranean clover in a cool, temperate environment. Agronomy Journal 91:122-127.

GIJZEN, M., MILLER, S.S., KUFLU, K., BUZZELL, R.I. \& MIKI, B.L.A. 1999. Hydrophobic protein synthesized in the pod endocarp adheres to the seed surface. Plant Physiology 120:951-959.

GILLIKIN, J. \& GRAHAM, J.S. 1991. Purification and developmental analysis of the major anionic peroxidase from the seed coat of Glycine max. Plant Physiology 96:214-220.

GUNN, C.R. 1981. Seed topography in the Fabaceae. Seed Science and Technology 9:737-757.

HAMLY, D.H. 1932. Softening of the seeds of Melilotus alba. Botanical Gazette 96:345-375.

HARRIS, W.H. 1987. Comparative ultrastructure of developing seed coats of 'hard-seeded' and 'soft-seeded' varieties of soybean, Glycine $\max (\mathrm{L}$.) Merril. Botanical Gazette 148:324-331.

HILL, H.J., WEST, S.H. \& HINSON, K. 1986. Effect of water stress during seedfill on impermeable expression in soybean. Crop Science 26:807-812.
HOPKINSON, J.M. 1993. The strophiole of legume seeds. International Herbage Seed Production Research Group Newsletter 18:7-8.

HORLINGS, G., GAMBLE, E.E \& SHANMUGASUNDARAM, S. 1991. The influence of seed size and seed coat characteristics on seed quality of soybean in the tropics: field weathering. Seed Science and Technology 9:665685 .

HSU, K.H., KIM, C.J. \& WILSON, L.A. 1983. Factors affecting water uptake by soybeans during soaking. Cereal Chemistry 60:208-211.

HYDE, E.O.C. 1954. The function of the hilum in some Papilionaceae in relation to the ripening of the seed and the permeability of the testa. Annals of Botany 18:241-256.

JHA, S.S. \& PANDEY, A.K. 1989. Seed coat structure in Melilotus (Fabaceae). Phytomorphology 32:221-229.

KANTAR, F., PILBEAM, C.J. \& HEBBLETHWAITE, P.D. 1996. Effect of tannin content of faba bean (Vicia faba) seed on seed vigour, germination and field emergence. Annals of Applied Biology 128:85-93.

KORBAN, S.S., COYNE, D. \& WEIHING, J.L. 1981. Rate of water uptake and sites of water entry in seeds of different cultivars of dry bean. HortScience 16:545-546.

KOUL, K.K., NAGPAL, R. \& RAINA, S.N. 2000. Seed coat microsculpturing in Brassica and allied genera (Subtribes Brassicinae, Ralphaninae, Moricandiinae). Annals of Botany 86: 385-397.

KRZYZANOWSKI, F.C., FRANÇA NETO, J.B. de, KASTER, M. \& MANDARINO, J.M.G. 1999. Metodologia para seleção de genótipos de soja com semente resistente ao dano mecânico - relação com o conteúdo de lignina. In Resultados de pesquisa da Embrapa Soja. 1998. Londrina, EMBRAPA/CNPSo, p.213-214.

KULIK, M.M. \& YAKLICH, R.W. 1991. Soybean seed coat structures: relationship to weathering resistance and infection by the fungus Phomopsis phaseoli. Crop Science 31:108-113.

KUO, W.H.J. 1989. Delayed permeability of soybean seeds: characteristics and screening methodology. Seed Science and Technology 17:131-142.

La SCALA JR., N., FLORENTINO, A.O. \& CARVALHO, N.M. 1999. Differences and similarities in the pore size distribution of soybean seed coats. Seed Science and Technology 27:365-369.

LACEY E.P., SMITH, S. \& CASE, A. L. 1997. Parental effects on seed mass: seed coat but not embryo/endosperm effects. American Journal of Botany 84:1617-1620.

LEGESSE, N. \& POWELL, A.A. 1996. Relationship between the development of seed coat pigmentation, seed coat adherence to the cotyledons and the rate of imbibition during the maturation of grain legumes. Seed Science and Technology 24:23-32.

LUSH, W.M. \& EVANS, L.T. 1980. The seed coats of cowpeas and other grain legumes: structure in relation to function. Field Crop Research 3:267-286.

MARBACH, I. \& MAYER, A.M. 1974. Permeability of seed coats to water as related to drying conditions and metabolism of phenolics. Plant Physiology 54:817-820.

MARCOS-FILHO, J. 1994. Teste de envelhecimento acelerado. In Testes de vigor em sementes (R.D. Vieira \& N.M. Carvalho, eds.). Funep, Jaboticabal, p.133-149. 
MAXEY, A.M. \& DELOUCHE. J.C. 1980. Storage and viability of impermeable soybean seed. Agronomy Abstracts, American Society of Agronomy. p.111.

MAYER, A.M. \& POLJAKOFF-MAYBER, A. 1975. The germination of seeds. $3^{\text {rd }}$ ed. Pergamon, New York.

McDONALD, C.K. 2000. Variation in the rate of hard seed breakdown of twelve tropical legumes in response to two temperature regimes in the laboratory. Australian Journal of Experimental Agriculture 40:387-396.

McDONALD JR., M.B., VERTUCCI, C.W. \& ROOS, E.C. 1988a. Soybean seed imbibition: water absorption by seed parts. Crop Science 28:993-997.

McDONALD JR., M.B., VERTUCCI, C.W. \& ROOS, E.C. 1988b. Seed coat regulation of soybean imbibition. Crop Science 28:987-992.

MILLER, S.S., BOWMAN, L.A., GIJZEN, M. \& MIKI, B.L.A. 1999. Early development of the seed coat of soybean. Annals of Botany 84:297-304.

MUGNISJAH, W.Q., SHIMANO, I. \& MATSUMOTO, S. 1987. Studies on the vigor of soybean seeds. II. Varietal differences in seed coat quality and swelling components on seed during moisture imbibition. Journal of the Faculty of Agriculture, Kyushu University, 3:227-234.

MULLIN, W.J. \& XU, W. 2000. A study of the intervarietal differences of cotyledon and seed coat carbohydrates in soybeans. Food Research International 33:883-891.

NAKAMURA, S. 1962. Germination of legume seeds. Proceedings of the International Seed Testing Association 27:694-709.

NOODÉN, L.D., BLAKLEY, K.A. \& GRZYBOWSKI, J.M. 1985. Control of seed coat thickness and permeability in soybean. Plant Physiology 79:543-545.

OLIVEIRA, M.D., MATTHEWS, S. \& POWELL, A.A. 1984. The role of split seed coats in determining seed vigour in commercial seed lots of soybean, as measured by the electrical conductivity test. Seed Science and Technology 12:659-668.

OWEN, E.B. 1956. The storage of seeds for maintenance of viability. Bulletin 43. Commonwealth Bureau of Pastures and Field Crops. Hurley, U.K.

PANOBIANCO, M. \& VIEIRA, R.D. 1996. Electrical conductivity of soybean soaked seeds. I. Effect of genotype. Pesquisa Agropecuária Brasileira 31:621627.

PANOBIANCO, M., VIEIRA, R.D., KRZYZANOWSKI, F.C. \& FRANÇA-NETO, J.B. 1999. Electrical conductivity of soybean seed and correlation with seed coat lignin content. Seed Science and Technology 27:945-1000.

PEREIRA, L.A.G. \& ANDREWS, C.H. 1985. Comparison of non-wrinkled and wrinkled soybean seed coats by scanning electron microscopy. Seed Science and Technology 13:853-860.

PESKE, S.T. \& PEREIRA, L.A.G. 1983.Tegumento da semente de soja. Tecnologia de Sementes 6:23-34.

POTTS, H.C., DUANGPATRA, J., HAIRSTON, W.G. \& DELOUCHE, J.C. 1978. Some Influences of hardseededness on soybean seed quality. Crop Science 18:221-224.

POWELL, A.A. 1989. The importance of genetically determined seed coat characteristics to seed quality in grain legumes. Annals of Botany 63:169-175.
PRETE, C.E.C., CÍCERO, S.M. \& FOLEGATI, M.V. 1994. Emergência de plântulas de soja no campo e sua relação com a embebição e condutividade elétrica das sementes. Semina 15:32-37.

RAGUS, L.N. 1987. Role of water absorbing capacity in soybean germination and seedling vigour. Seed Science and Technology 15:285-296.

RAMSAY, G. 1997. Inheritance and linkage of a gene for testa-imposed seed dormancy in faba bean (Vicia faba L.). Plant Breeding 116:287-289.

ROLSTON, M.. 1978. Water impermeable seed dormancy. Botanical Review 44:365-396.

SAIO, K. 1976. Soybeans resistant to water absorption. Cereal Foods World 21:168-173.

SEFA-DEDEH, S. \& STANLEY, D.W. 1979. The relationship of microstructure of cowpeas to water absorption and dehulling properties. Cereal Chemistry 56:379-386.

SILVA, A.A., CARMELlO, S.M. \& NAKAGAWA, J. 1988. Germinação e vigor sementes de Crotalaria lanceolata E.Mey. I. Influência da cor do tegumento e da posição dos frutos na infrutescência. Revista Brasileira de Sementes 10:67-73.

SIMÃO NETO, M., JONES, R.M. \& RATCLIFF, D. 1987. Recovery of pasture seed fed to ruminants. I. Seed of tropical pasture species fed to cattle, sheep and goats. Australian Journal of Experimental Agriculture 27:239-246.

SLATTERY, H.D., ATWELL, B.J. \& KUO, J. 1982. Relationship between colour, phenolic content and impermeability in the seed coat of various Trifolium subterraneum L. genotypes. Annals of Botany 50:373-378.

SOUZA, F.H.D. \& MARCOS-FILHO, J. 1993. Physiological characteristics associated with water imbibition by Calopogonium mucunoides Des. seeds. Seed Science and Technology 21:561-572.

SOUZA, F.H.D., MARCOS-FILHO, J. \& NOGUEIRA, M.C.S. 1996. Características físicas das sementes de Calopogonium mucunoides associadas a absorção de água e qualidade fisiológica. I. Tamanho. Revista Brasileira de Sementes 18:33-40.

SPURNÝ, M. 1973. The imbibition process. In Seed ecology (W. Heydecker, ed.). Chapter 21, University Park, The Pennsylvania State University, p.367-389.

SWANSON, B.G., HUGHES, J.S. \& RASMUSSEN, H. 1985. Seed microstructure: review of water imbibition in legumes. Food Microstructure 4:115-124.

TAVARES, D.Q., MIRANDA, M.A.C., UMINO, C.Y. \& DIAS, G.M. 1987. Características estruturais do tegumento sementes de linhagens de soja permeável e impermeável. Revista Brasileira de Botânica 10:147-153.

TINIUS, C. 1991. Variable expression of seedcoat permeability. Soybean Genetics Newsletter 18:256-259.

TIWARI, S.P. \& HARIPRASAD, A.S. 1997. Selection criteria for seed longevity in soya bean [Glycine $\max (\mathrm{L}$.$) Merr.].$ Tropical Agriculture 74:70-72

TULLY, R.E., MUSGRAVE, M.E. \& LEOPOLD, A.C. 1981. The seed coat as a control of imbibitional chilling injury. Crop Science 21:312-317.

VALENTI, G.S., MELONE, L., FERRO, M. \& BOZZINI, A. 1989. Comparative studies on testa structure of 'hardseeded' and 'soft-seeded' varieties of Lupinus angustifolius L. (Leguminosae) and on mechanisms of water entry. Seed Science and Technology 17:563-581. 
VAUGHAN, D.A., BERNARD, R.L., SINCLAIR, J.B. \& KUNWAR, I.K. 1987. Soybean seed coat development. Crop Science 27:759-765.

VAUGHAN, D.A., KUNWAR, I.K., SINCLAIR, J.B. \& BERNARD, R.L. 1988. Routes of entry of Alternaria sp. into soybean seed coats. Seed Science and Technology, 16:725-731.

VERMA, V.D. \& RAM, H.H. 1986. Heritability estimates for seed quality traits in soybeans. Soybean Genetics Newsletter, 13:67-70.

VIEIRA, R.D. 1994. Teste de condutividade elétrica. In Testes de vigor em sementes (R.D. Vieira \& N.M. Carvalho, eds.). Funep, Jaboticabal, p.103-132.

VIEIRA, R.D., PAIVA, J.A. \& PERECIN, D. 1999. Electrical conductivity and field performance of soybean seeds. Seed Technology 21:15-24.

VIEIRA, R.D., PANOBIANCO, M., LEMOS, L.B. \& FORNASIERI-FILHO, D. 1996. Efeito de genótipos de feijão e de soja sobre os resultados da condutividade elétrica de sementes. Revista Brasileira de Sementes 18:220-224.
WERKER, E., MARBACH, I. \& MEYER, A.M. 1979. Relationship between the anatomy of the testa, water permeability and presence of phenolics in the genus Pisum. Annals of Botany 43:765-771.

WIEN, H.C. \& KUENEMAN, E.A. 1981. Soybean seed deterioration in the tropics: II. Varietal differences and techniques for screening. Field Crops Research 4:123132.

WOLF, W.J., BAKER, F.L. \& BERNARD, R.L. 1981. Soybean seed coat structural features: pits, deposits and cracks. Scanning Electron Microscopy 3:531-544.

WOODSTOCK, L.W. 1988. Seed imbibition: a critical period for successful germination. Journal of Seed Technology 12:1-15.

YAKLICH, R.W., VIGIL, E.L. \& WERGIN, W. 1984. Scanning electron microscopy of soybean coat. Scanning Electron Microscopy 2:991-1000.

YAKLICH, R.W., VIGIL, E.L. \& WERGIN, W. 1986. Pore development and seed coat permeability in soybean. Crop Science 26:616-624. 